\title{
MILITARY BROWNFIELDS - POTENTIAL FOR TOURIST REVITALIZATION IN BOSNIA AND HERZEGOVINA
}

\author{
Snježana MUSA* \\ University of Mostar, Study of Geography, Faculty of Science and Education, Matice \\ hrvatske bb, 88 ooo Mostar, Bosnia and Herzegovina, e-mail: snjezamusa@gmail.com \\ Dario ŠAKIĆ \\ University of Mostar, Study of Geography, Faculty of Science and Education, Matice \\ hrvatske bb, 88 ooo Mostar, Bosnia and Herzegovina, e-mail: dario.a.sakic@gmail.com
}

Citation: Musa, S. \& Šakić, D. (2019). MILITARY BROWNFIELDS - POTENTIAL FOR TOURIST REVITALIZATION IN BOSNIA AND HERZEGOVINA. GeoJournal of Tourism and Geosites, 26(3), 1021-1032. https://doi.org/10.30892/gtg.26326-414

\begin{abstract}
The existence and origin of "abandoned military facilities" has not exclusively related to geopolitical changes from the late 2oth century. There are numerous abandoned military facilities in the world, ranging from conquering America to modern war shelter and warehouses. These objects were abandoned because of either changes in the doctrine of war, technology changes or the withdrawal of new frontiers. Their regeneration is primarily related to the interest of local authorities, such as the case with Albania, where abandoned bunkers are used for tourism development where they serve as accommodation facilities. Contemporary research of military brownfields tells the world that they are using as places for new tourist destinations, or for functional purposes such as administrative and residential buildings, warehouses, garages, etc. It is a fact that almost all urban areas in Bosnia and Herzegovina had barracks, so revitalization is carried out precisely from this point of view: one becomes a room for organizing university campuses or other public institutions. Other facilities especially those in rural areas are problematic, they are sources of pollution. The most obvious example is the object "Courage Barbara” in the Glamoč karst field, which is abundant with problems, such as those related to property legal relations and the wider dimensions of ecological disasters with far-reaching and hard-foreseeable consequences. There is a number of military bases as potential objects of tourist interest with exquisite landscape elements and enormous capacities.
\end{abstract}

Key words: Military brownfields, Bosnia and Herzegovina, functional transformation, touristic revitalization

\section{INTRODUCTION}

The brownfields concept has been popularized since the 1960 s and has been linked to devastated and abandoned land in the process of de-industrialization and

\footnotetext{
* Corresponding author
} 
internationalization. The expression began to spread to other areas of appearance, both in terms of traffic structure and abandoned farmland, but it is starting to be more forcefully used by the abandoned military areas and facilities. Works from the aforementioned field are not common, but we cite some of them: Syms, 1999; Litt \& Burke, 2002; Dixon, 2006; Thornton et al., 2007; Wedding \& Crawford-Brown, 2007 and others.

With respect to the concept of brownfields, there is still a lack of common understanding of the term itself. Urban designer, architects and economists, as well as geographers and ecologists are dealing with brownfields objects. As stated by Sýkorová (2007), brownfields research comes first, especially in the context of sustainable development, urban expansion and revitalization of city centers. Most authors approach to brownfields research through urban landscape issues (Novosák \& Szcyrba, 2004), but it should be emphasized that these studies are related to urban areas. Brownfields also appear in villages, where is observed significant degradation of economic activity (Svobodová \& Věžník, 2009). Often is in the literature discussed on their regeneration (Hercik et al., 2014) in the context of the construction of new or non-productive facilities and the design of Greenfields. The experiences of Eastern European countries show that their brownfields are primarily taken over by foreign investors, for which rapid return on capital is one of the key factors in their investment in mind of new business buildings (Botić, 2013) and premises (shopping centers, offices and flats). This is also the case in Bosnia and Herzegovina, where there are obvious examples in Zenica with a steel mill.

On the other hand, in developed market economies, regeneration is more often associated with brownfield sites and the application of public-private partnerships (Kalberer et al., 2005) and projects that have no purely commercial nature. Project for "Blue Hospital" in Bugojno is example for that kind of use of brownfields. However, that project has never come in realization. The purpose of that project is effectively design a redevelopment plan for the site of this former regional hospital, producing community space that promotes peace and reconciliation between the ethnic groups affected by conflict utilizing landscape processes and a program of socially based activities such as community gardening and food production (Figure 1) (Frank, 2015).

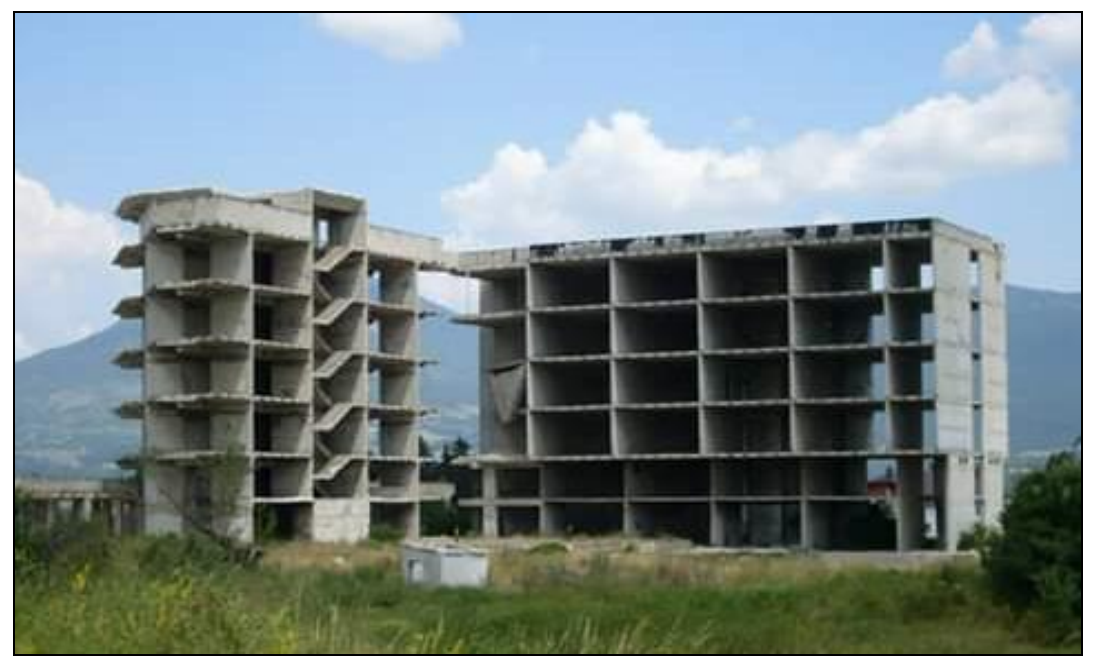

Figure 1. "Blue Hospital" in Bugojno today

In the brownfields regeneration process, it should be taken into account that they directly affect the possibilities of regeneration but also the factors that operate at a 
higher state level (Dasgupta \& Tam, 2009; Frantál et al., 2013). The range of factors affecting development and the potential of brownfield regeneration ranges from macro across the field to micro level, ie from institutional to economic and ecological impact on social and demographic conditions in space.

\section{MILITARY BROWNFIELDS - MILITARY ABANDONED FACILITIES IN BOSNIA AND HERZEGOVINA}

Some countries, for example USA, United Kingdom, France and West Germany, have long-term experience with the problems of brownfields, which had emerged already during the 1970s as a result of massively (Musa \& Šiljković, 2011) declining mining, heavy industries and textiles. In comparison, in countries such as the Czech Republic, Slovakia, East Germany, Poland or Romania, brownfields appeared in large quantities just after the collapse of socialism with the centrally planned economy and return of a market economy and the following globalization trends during the last decade of the 2oth century (Frantál et al., 2013). Subsequently, in the 1990s the military assets were reduced and certain transportation infrastructure was abandoned, thus these sites are added to brownfield sites. During and after this period the cycle of sites restructuring and their redevelopment was initiated (Kurtovic et al., 2014). As many countries in the Balkan region suffered from the consequences of deindustrialisation, Bosnia and Herzegovina (Picer et al., 2004) was affected by the sudden appearance of brownfield areas, especially in the course of the 20th century after progressive destruction induced by the 1992-1995 war (Gegic \& Husukic, 2017). The geographic position and characteristics of the territory of Bosnia and Herzegovina contributed to the extremely high concentration of the military industry before the war during 1990s. Bosnia and Herzegovina is a typical mountain country with an average altitude of $750 \mathrm{~m}$. Even $53.2 \%$ of the territory is located in the hypsometric area of 500 to 1500 meters. Numerous deep valleys, coves, canyons and rivers were ideal places for military shelters and warehouses, and mountain peaks over 2000 meters were excellent for basement pools, while high fields in karst used for military exercises, and today are polygons for destroying obsolete weapons and tools.

In the period from 1945 to 1992, Bosnia and Herzegovina was part of Social Federal Republic of Yugoslavia and as a centrally-laid republic played the role of a kind of military base, enough "hidden from potential enemies" and exceptionally advantageously geographically predestinated for the construction and preservation of numerous military bases, warehouses, shelters, polygons and other military facilities. Therefore, it happened that Bosnia and Herzegovina has a highly developed heavy and processing industry, but also optical industry in Konjic, Bugojno, Sarajevo, production of explosives was in facilities in Novi Travnik, etc. There are many atomic shelters, such as in Konjic, and big areas of quality agricultural land were captured in camps on Manjaca and Zmijanje, Kalinovik, Han Pijesak and Glamoc. In the 1960s, one of the largest artillery bases of the former Yugoslav People's Army was built on the slopes of the Manjaca Plateau.

This has led to the disappearance of many villages, the emigration of the population, the abandonment of traditional cattle breeding. Before the war in the area of Bijelo polje near Mostar there was a polygon for the destruction of the battle poisons. In the former Socialist Republic of Bosnia and Herzegovina, it is mainly invested in the military industry, especially in the construction of military bases. Bosnia and Herzegovina was the border between the western and eastern military districts. These facts also indicate that, in part, the territory of Bosnia and Herzegovina was pre-ordained for the war between 1992 and 1995. The war that occurred here had incredible resources in educated personnel, in finished military products and in facilities for their manufacture. Military facilities within urban environments (Simonović, 2013) have a multifaceted 
character and can be easily transformed into residential, commercial and often educational, cultural or productive purposes. Part of the rural areas are intended for recreation, mixing of some production or storage capacities and so on.

Due to the many problems and their consequences, stemming from the use and maintenance of military brownfields this problem has been initiated for resolving in some countries but not in Bosnia and Herzegovina. On the contrary, there are persistent irredeemable problems in Bosnia and Herzegovina with abandoned military technology, terrain and even modern pollution caused by military action.

\section{RESULTS AND DISCUSSIONS \\ Functional transformation of military brownfields in Bosnia and Herzegovina - the current state of affairs}

After the war, numerous areas as "military brownfields" remained, which are not cleaned today, and they are source of many drawbacks. Their development continues through the activation of the space for the destruction of weapons, such as Resolute Barbara Range (Figure 2), in the Glamoc field. This range was first used by SFOR (The Stabilisation Force) in 1996 under the General Framework Agreement for Peace.

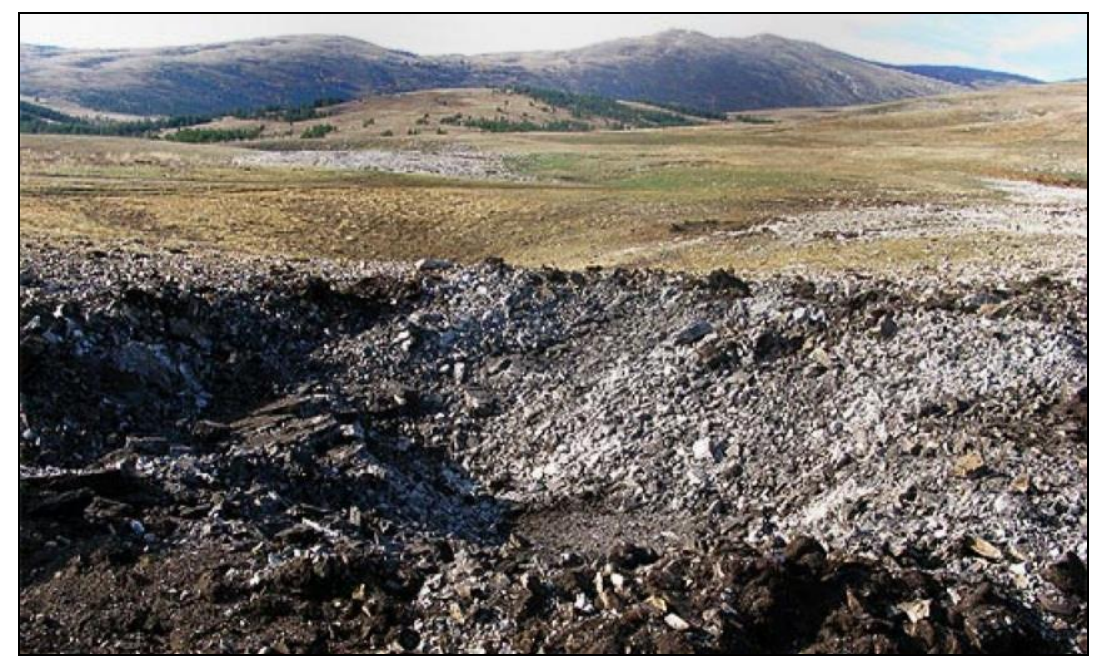

Figure 2. Destruction of weapons on Resolute Barbara Range (Photo: Hanka Džin Jahjaefendić, 2017)

This form of resource management has been introduced by the international community to stop the division of military facilities and what goes on with them, so there is no privatization. On the one hand, it may be good, but the other is bad because the time passes, and some objects, which are national monuments such as the beautiful architectural building with excellent position of Jajce Barracks in Sarajevo are collapsing. The second problem is that some items remain due to weathering; third is in some cases illegal privatization through recapitalization, etc. As we can see, military industry is still an important economic factor with a 112465 ooo BAM gained of export during first 8 months of 2018 (Agency for statistics of $\mathrm{B} \& \mathrm{H}$ ). Although there is not much left of this industry, there is enough basis for future development. When we speak of brownfield sites, it is important to emphasize the importance of investment in the process of their rehabilitation and reuse. Reduction of investment in brownfield sites occurred mainly in developed countries. The main reason for this, in addition to financial and credit constraints, is a high risk for this type of investment, and weak prospects for economic 
growth in the world (Kurtovic et al., 2014). The Armed Forces B\&H had an agreement with Sterling International, which is responsible for the implementation of the destruction of armaments and weapons in the Glamoc karst field, which is underground watershed between the Adriatic and Black Sea river basins. Although there are numerous problems related to unresolved legal cadastral relations and those related to environmental pollution, not only locally but regionally, the range is still in operation. The Federal Institute of Agropedology has conducted several analyzes on the Resolute Barbara Range where NATO and then the Armed Forces of B\&H destroyed armed surpluses. The data showed the presence of heavy metals in quantities greater than allowed, which could lead to serious illnesses. Local residents sued the State for compensation for damage done on private soil.

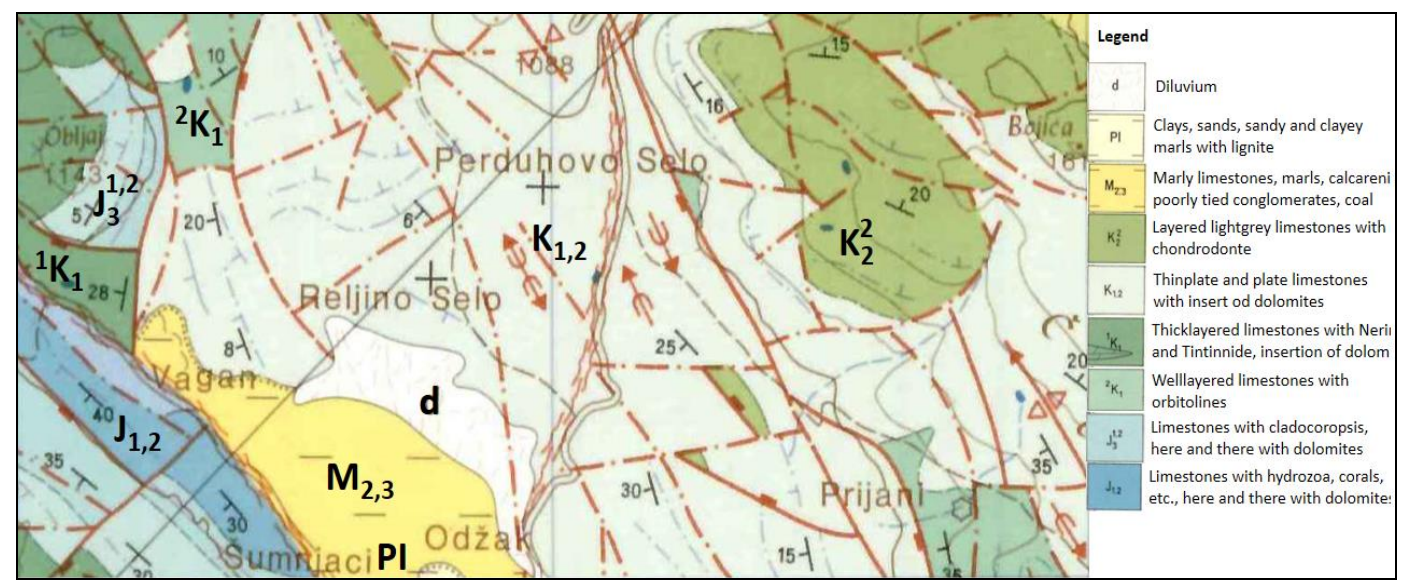

Figure 3. Resolute Barbara Range on the karst area below which is the underground watershed of the Adriatic and Black Sea river basin. On the geological map, you can see cracked karst, numerous faults and other karst forms, which indicate the potential contamination routes of both river basins. (Source: Geological map 1:100000, L33-142, Belgrade, 1978)

The number of abandoned military facilities is extremely large, and the problems that result from them are numerous. They are classified into several groups:

1. Mine fields as environmental pollution;

2. Resolute Barbara Range on the karst area below which is the underground watershed of the Adriatic and Black Sea river basin (see a geological map, Figure 3)

3. Abandoned facilities of military-technological parks such as Vitezit in municipality Novi Travnik;

4. Abandoned relays;

5. Abandoned military aerodromes

Military bases as potential tourist destination

There are numerous examples of transformation of military brownfields to public and business premises in Bosnia and Herzegovina, such as military facilities in center of major towns Sarajevo, Banja Luka, Mostar, Travnik - they are transformed in education (University campuses) and cultural facilities (libraries). Atomic shelter in Konjic (Figure 4) is today a museum titled "Titov bunker". There is a plan for the development of hotel accommodation in the same area. Numerous mountain centers, relays and so on have been turned into relay centers of television stations or telephones and mobile operator. Many of them are still in ruins and representing danger for humans because of their proximity to tourist sites. Based on this short analysis, some acute problems and localities can be distinguished: 
- Environment and Health: the biggest problem is the Resolute Barbara Range, which is the area of the destruction of weapons from the previous war.

- An example of large pollution is the detonation of deadly uranium bombs from the last war in Hadzici, Bjelasnica, Kalinovik and Han Pijesak, etc.

- Unfulfilled privatization causes decay of historical monuments such as Jajce Barracks in Sarajevo

- The current legal framework in B\&H does not allow the privatization of military facilities, thus preventing the revitalization of military brownfields throughout $\mathrm{B} \& \mathrm{H}$.

- Although there is a military database on military property, it is assumed that there is no database of military brownfields that would provide information on the number of the same and link them to risks to human health and environmental burdens.

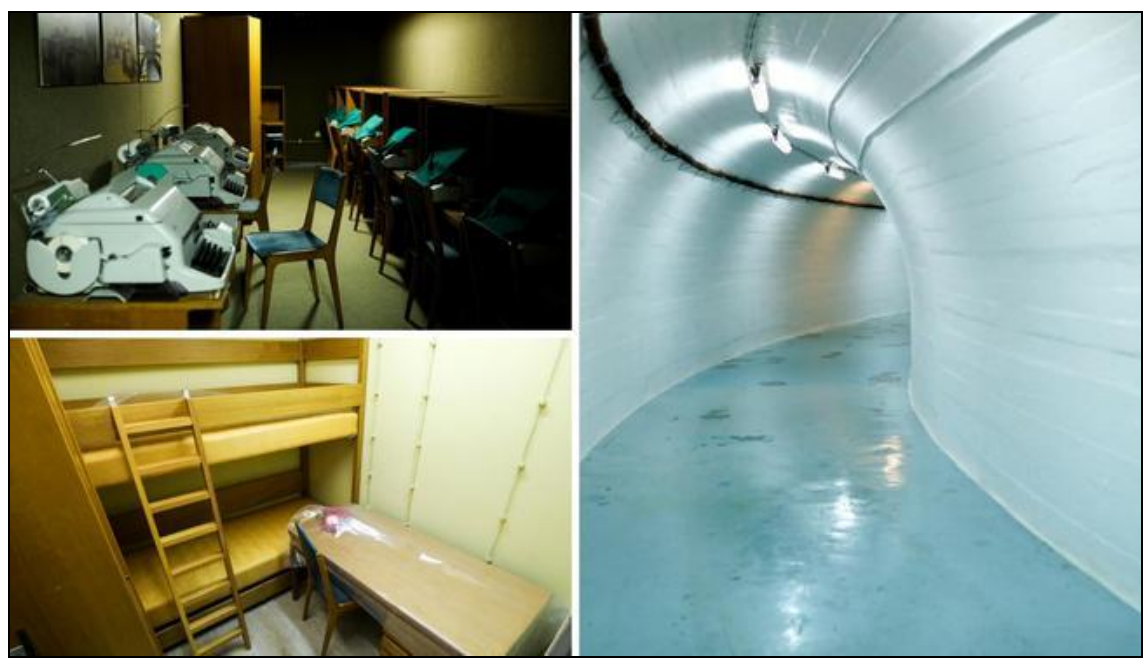

Figure 4. The Atomic shelter in Konjic is a museum-national monument of B\&H and a tourist destination

The status of military bases in the territory of $\mathrm{B} \& \mathrm{H}$ is different. Of course, those in larger urban areas are under the struggles between interests. In $\mathrm{B} \& \mathrm{H}$, these facilities are divided into perspective and non-perspectives military property. Perspective should be registered as property of $\mathrm{B} \& \mathrm{H}$. These are some of the strategic military bases.

Problem is different interests of Federation of B\&H and Republic of Srpska (RS) on these topics (Bijelić \& Filipović, 2016). The problem is that RS is seeking to adopt a comprehensive law that would cover all the assets of the former JNA (Yugoslav People's Army) and then postulate under that law. The Federation of B\&H first agreed to it, and then changed their minds and abandoned the law. Most of the unspoken military assets eventually are provided to local communities.

\section{Military brownfields - revitalization of potential tourist destinations}

Military brownfields have long been used as tourist destinations in the countries of Western Europe: the Netherlands, Norway, Denmark, Sweden, which made accommodation facilities from many of military facilities for example. During the period of transformation after 1989 we can note many processes in the post-communist countries which have considerably changed their politics on the one hand and their societies and economies on the other. These processes involve de-industrialisation, de-agrarianisation and demilitarisation as a part of geopolitical changes (Matlovič et al., 2001). According to Baskaya (2010) brownfields sites include several values, such as economic, historical, social, environmental, psychological, technological, spatial and ecological value (Figure 5). 


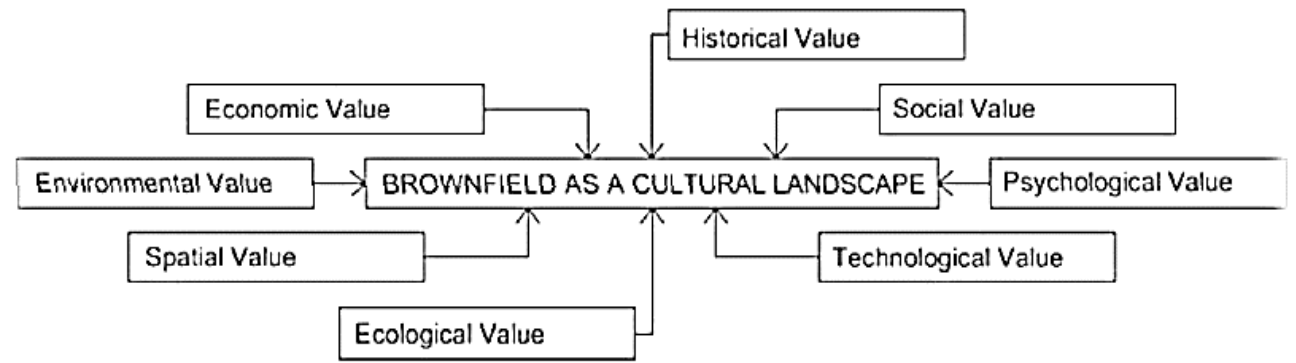

Figure 5. Value of brownfield sites (Source: Baskaya, 2010)

Only in the territory of Bosnia and Herzegovina, for almost fifty years, 17 facilities were designed for temporary placement and shelter of those "main" in state service (12 in Federation and 5 in RS). Most of them are built so that they can easily be revitalized and used for tourist purposes, either as accommodation, transport or recreational facilities. Although it is difficult to get information about them, the fact is that in the Spatial plan of Federation of B\&H there is a list of all military facilities that are categorized in perspective and non-perspective, and then by structure. Such data for RS could not be found.

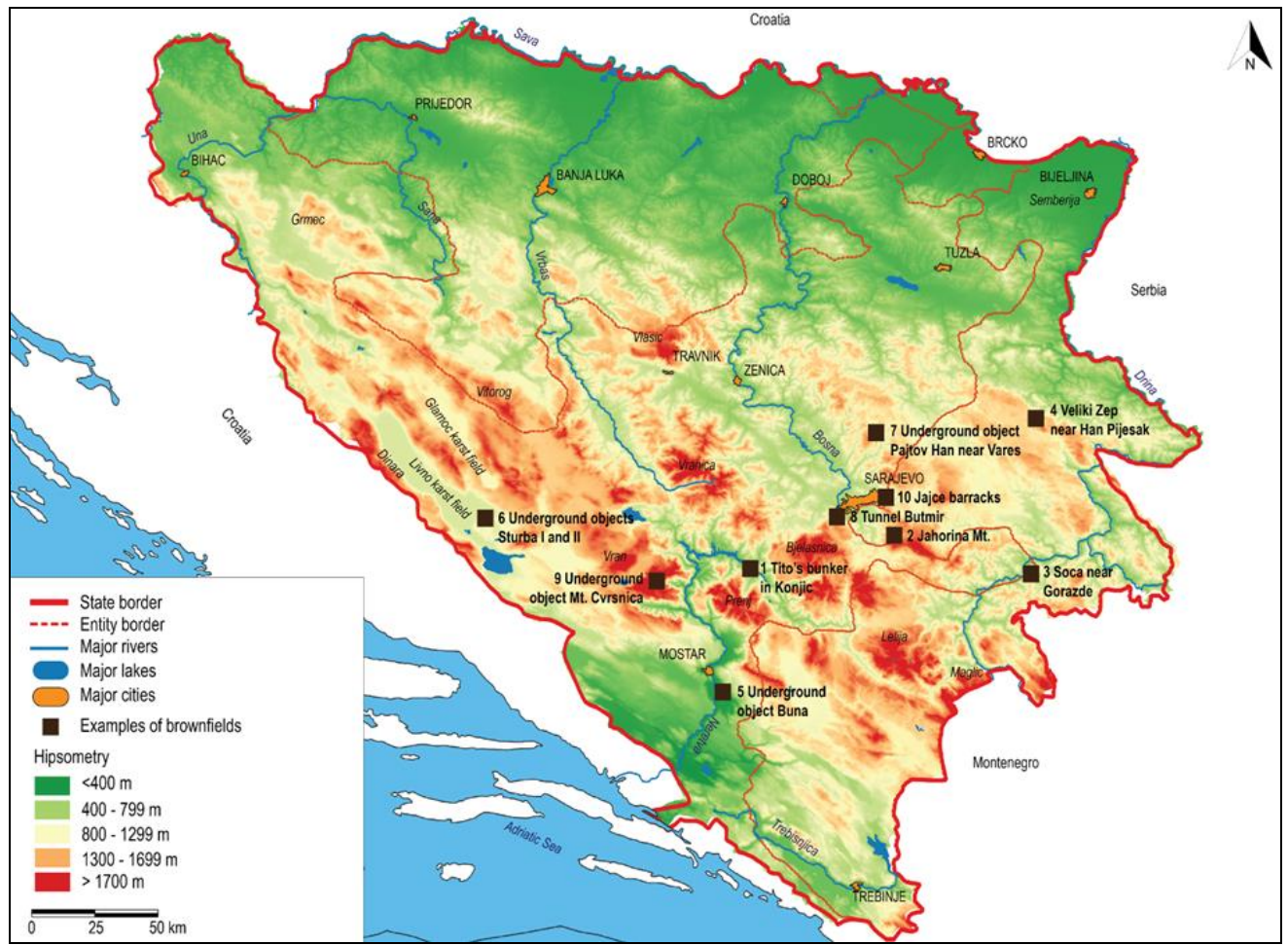

Figure 6. Geographical position of several brownfields in Bosnia and Herzegovina

Facilities intended for temporary placement and sheltering the state service: underground city in Konjic (Tito's bunker), Jajce barracks in Sarajevo, facilities in Jahorina Mt., underground city Soc near Gorazde, Veliki Zep near Han Pijesak, underground facility in Buna, facilities in Livno municipality (Sturba 1 and 2), Ljepunica near Pazaric, Pajtov han near Vares, war tunnel in Butmir, Vitorog Mt., Cvrsnica Mt., 
Bjelasnica Mt. Military brownfields can also be a valuable asset for the development of tourism in Bosnia and Herzegovina, as a cultural resource whose inclusion in the tourist offer would increase its attractiveness and enrich it with unusual activities (Figure 6).

1. Tito's bunker in Konjic

Atomic war command, also known as the Ark and nicknamed Tito's bunker, is a former nuclear bunker and military command center located near the town of Konjic in Bosnia and Herzegovina. Built to protect Yugoslav President Josip Broz Tito and up to 350 members of his inner circle in the event of an atomic conflict, the structure is made up of residential areas, conference rooms, offices, strategic planning rooms, and other areas. The bunker remained a state secret until after the breakup of Yugoslavia in the 1990s. Built between 1953 and 1979 inside a hill at the foot of the Zlatar Mountain, the ARK is the largest nuclear shelter, and one of the largest underground facilities, ever built in the former Yugoslavia. For over a decade after its completion, it was the most secret military installation in the country. All construction workers were carefully selected and vetted, signing a contract of silence, and all staff members held the highest security clearance. In 1979, when work was completed after 26 years and $\$ 4.6$ billion in construction costs (https://www.bunker.ba, 8th March 2019).

2. Jahorina Mt.

On every higher mountain in $\mathrm{B} \& \mathrm{H}$ there are underground facilities, and the larger one is on the top of the Jahorina Mt. near Sarajevo, under the hotel for military pilots that the Americans bombed in 1995. The overground part was demolished, but the underground was not seriously damaged (Figure 7).

3. Underground object "Soca" near Gorazde

His area is 15000 sq meters. Amongst other things, there were 98 numbered offices and rooms. There are also two larger meeting rooms, an ambulance area and a large restaurant. Most of facilities are destroyed, and some of them are used for mushroom production (Figure 8).

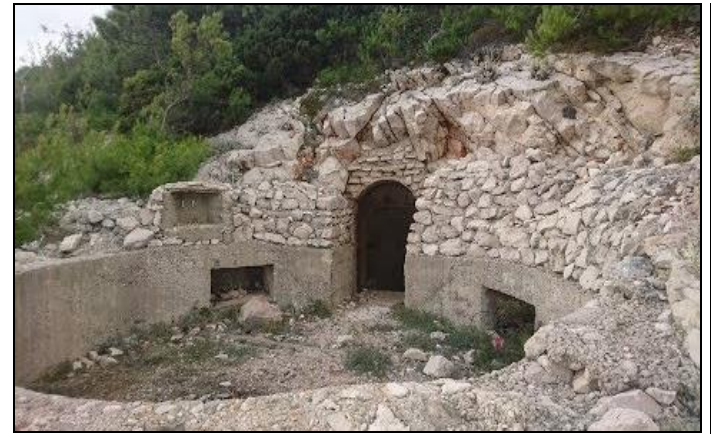

Figure 7. Underground facilities on the top of the Jahorina Mt

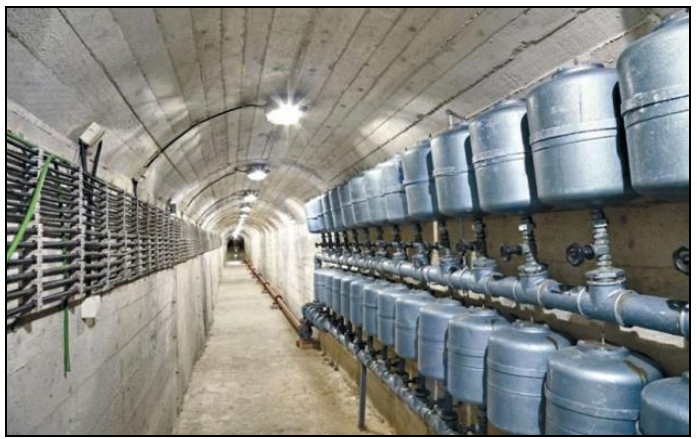

Figure 8. Underground object "Soca" near Gorazde (Photo: Zeljko Delic, 2015)

4. Veliki Zep near Han Pijesak

That is an underground bunker, built as the main command center in the event of a new war. The bunker is seven miles away from Han Pijesak and today it is devastated and closed (Figure 9).

5. Underground object Buna

It is located on the road Mostar-Blagaj, directly next to the Mostar Airport, connected to the access routes used for the departure of the aircraft to the main runway. The completely underground facility consists of two tunnels intended for hiding helicopters and airplanes. It was built in the period from 1969 to 1971 (Figure 10). During the war in Mostar and its surroundings, this facility was destroyed. 
6. Underground objects Sturba 1 and 2 near Livno

They are now used as a warehouse for military artillery. During the last war in B\&H it had function of military hospital (Figure 11).
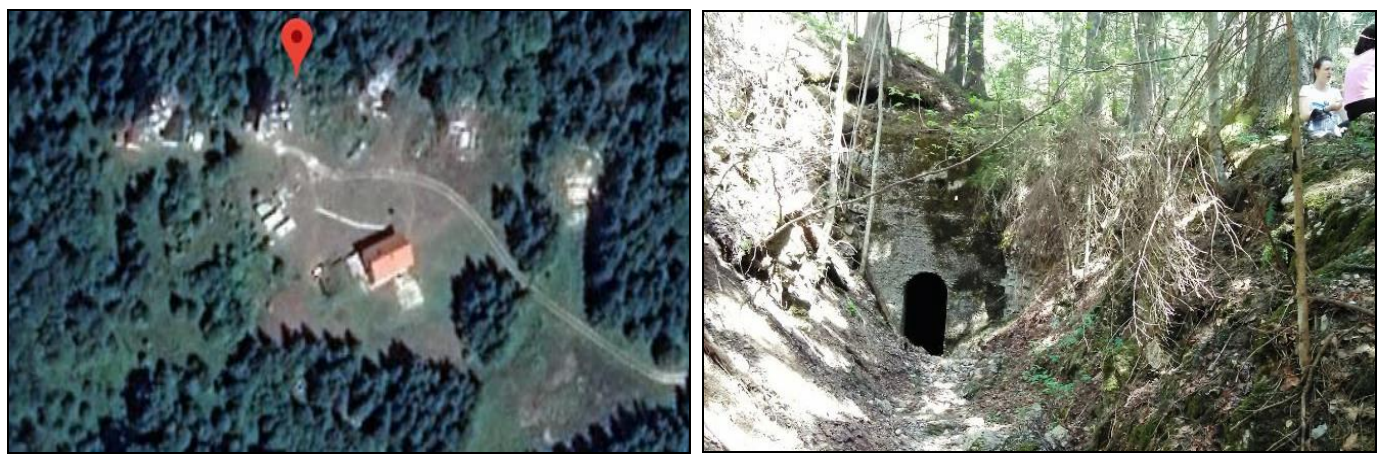

Figure 9. Underground bunker Veliki zep, Han Pijesak

(Google maps (visited on 27/8/2019) and Zeljko Delic, 2009)
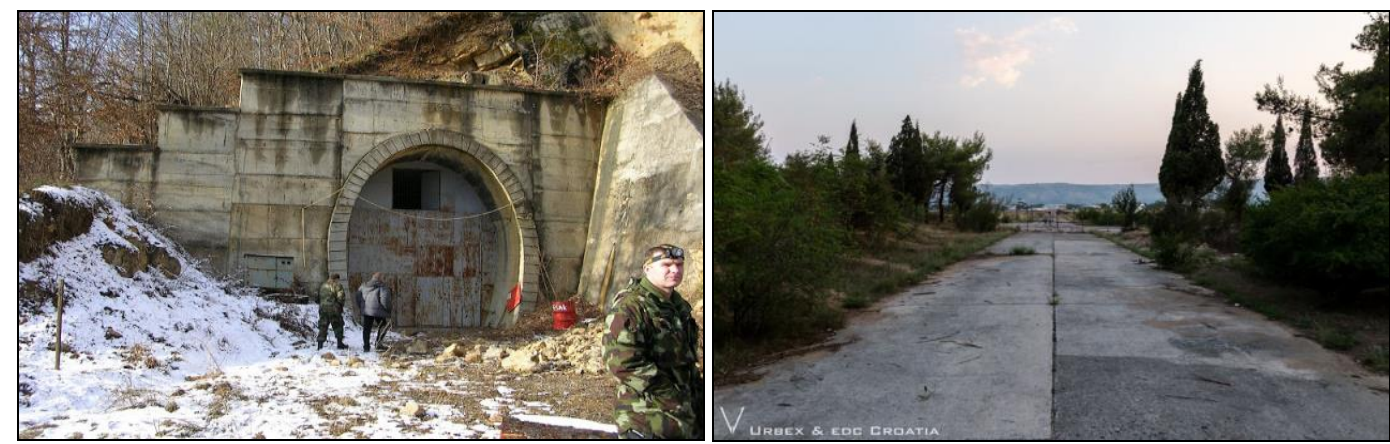

Figure 10. Entrance and access to underground structures Buna, near Mostar
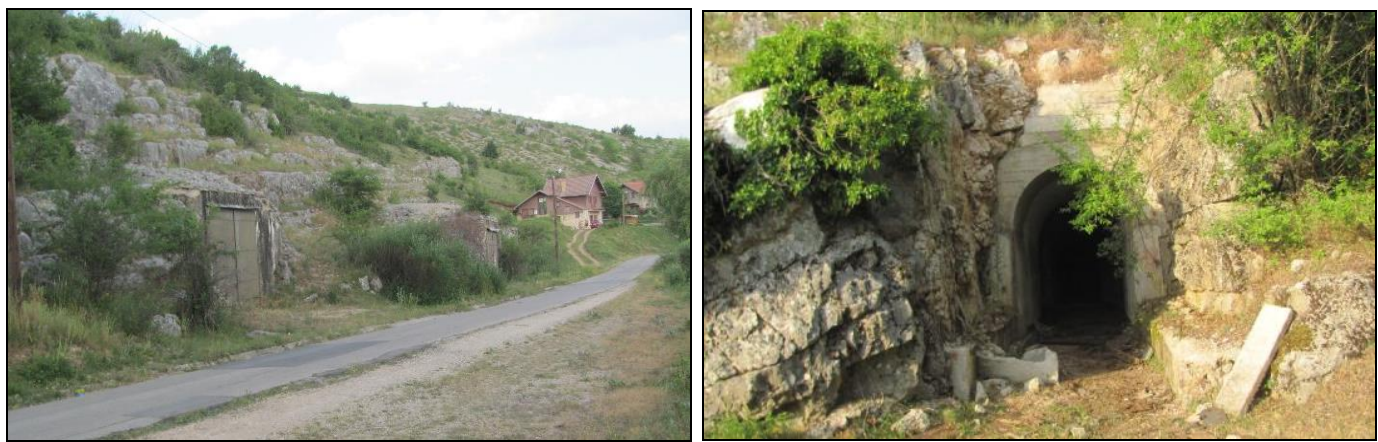

Figure 11. Underground objects Sturba 1 and 2, near Livno

7. Underground object Pajtov han near, Vares

Pajtov han represents a military object in two levels, a maze, about 500 meters long. Its capacity is 130,000 cubic meters, making it one of the largest terminal for strategic reserves in the areas of former Yugoslavia. It should have been a storage space for petroleum products. There are dozens of business backyard facilities, deep in the woods. During the time it is being destroyed (Figure 12). 


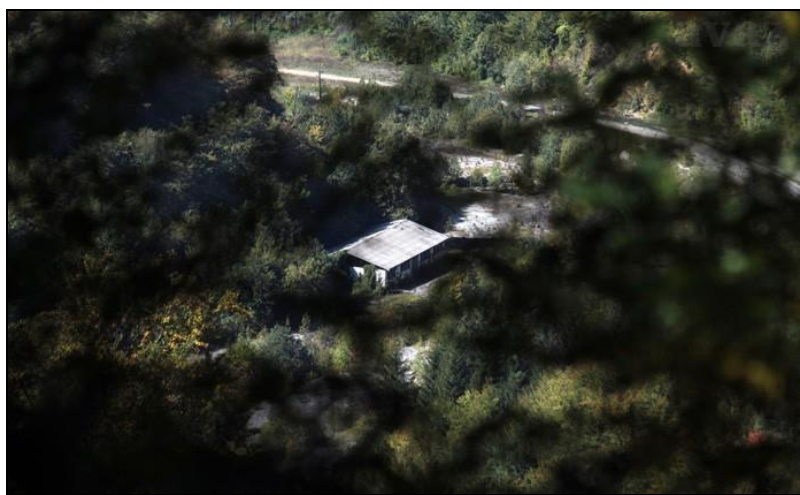

Figure 12. Underground object Pajtov han near Vareš (Photo: Roman Petrovic, 2016)

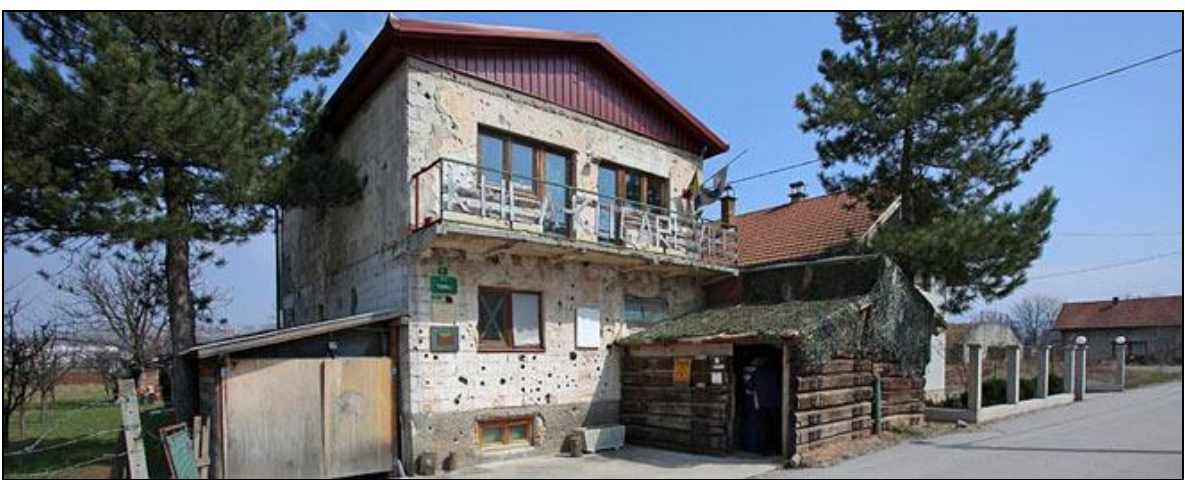

Figure 13. Entrance to the war tunnel in Sarajevo's Butmir settlement

8. Tunnel Butmir near Sarajevo

It is underground tunnel, which was used as communication between Sarajevo and Igman Mt. during the last war in B\&H. Tourists visit it and it is in every tourist offer in Sarajevo (Figure 13).

9. Underground object on Mt. Cvrsnica

There is a military facility built before the war as a relay hub, a surveillance and eavesdropping object. Prior to the war, besides the military bases, there was a hydrometeorological station that had an extraordinary role in recording climatic data, as the location of this site is shifting continental and maritime influences. Today, this is an active military facility, and we think it would be far more cost-effective and more interesting to be offered to tourists, as the view goes to Adriatic Sea (Figure 14).

10. Barracks "Jajce" in Sarajevo

In today's form completed in 1914. By construction it is the most complex military object in $\mathrm{B} \& \mathrm{H}$ from the Austro-Hungarian period, whose construction and development are closely related to the history of Sarajevo. It is declared a national monument of B\&H, but $80 \%$ of the complex is devastated. Numerous armies were held in the barracks, from the Austro-Hungarian, Yugoslav People's Army, to the Army of the Republic of B\&H and the Armed Forces of B\&H. It is located in the east of the city, within the old town Vratnik, on the plateau of the southern part of the remains of the medieval old town. It has an ideal position the hotel complex of high category in place of the ideal viewing point (Figure 15).

According to Badiali et al. (2018) this could be an important instrument and basis for future actions on urban landscape, not only for tourist development and information of citizens, but also for territorial planning. 


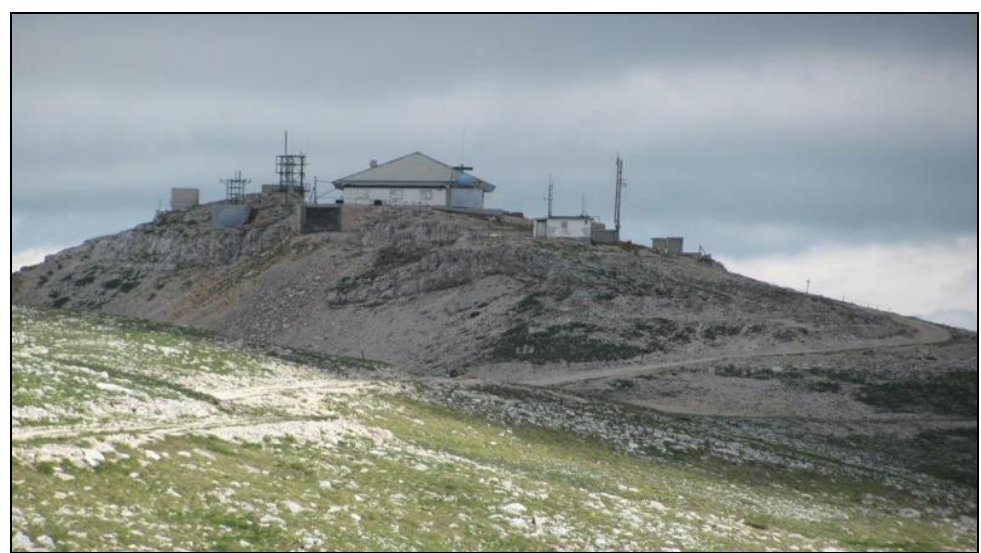

Figure 14. From the military facility on Mount Čvrsnica you can see the whole of Herzegovina

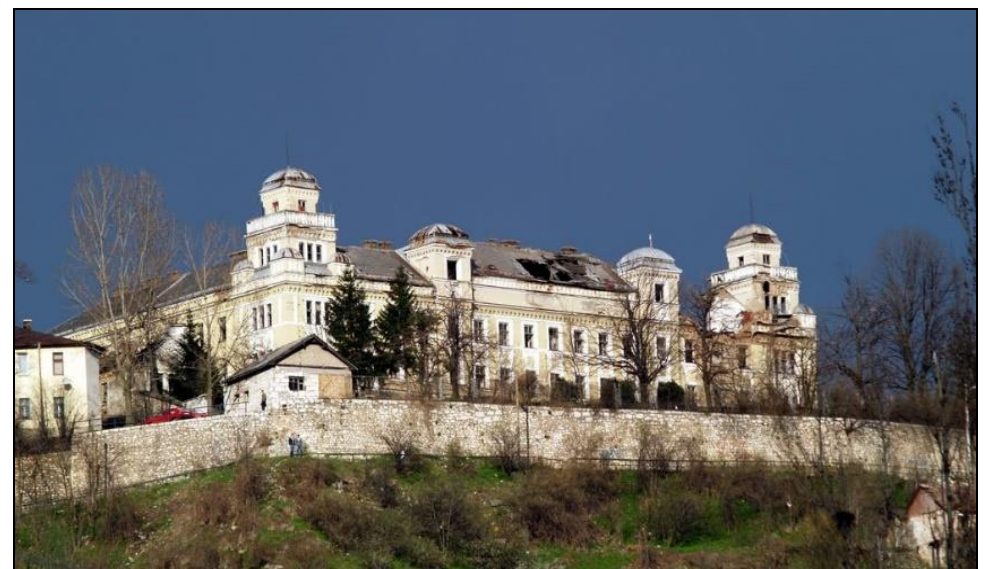

Figure 15. Example of the „Jajce“ Barracks in Sarajevo: Exceptional architectural structure, the national monument of $\mathrm{BiH}$, in a ruined state - extraordinary predisposition to high-class hotel

\section{CONCLUSION}

"Military brownsfield" in B\&H are very numerous. Property relations and entity interests do not lead to solving problems related to them. They are somewhere in the function of public institutions as universities, sometimes they serve for museum purposes, but are often our disgrace and the source of environmental problems, such as Resolute Barbara Range and destroyed raley on Bjelasnica Mt. Positive examples are rare, one of them is Tito's bunker in Konjic, which is at least somehow attracted to tourist exploitation. In $\mathrm{B} \& \mathrm{H}$, there are still at least 10 potential tourist destinations that link to military brownfields, and among the most interesting are: Jajce barracks in Sarajevo, facilities on Jahorina Mt., Underground city of Soč, Underground facilities Veliki Zep, underground facilities near Buna, Sturba 1 and 2 near Livno, Ljepunica near Pazarić, Pajtov han near Vareš, Butmir, Vitorog Mt., Čvrnica Mt., Bjelašnica Mt. It is a public secret that the land of numerous barracks in $\mathrm{BiH}$ has long been the focus of building lobbies, who see the opportunity to bargain cheaply in cities with ready-made infrastructure. Although this problem in B\&H has support at different levels, there seems to be a stronger current in which local spatial development is influenced primarily by politics, and it makes a decision on sales consistent with politics. Changes cannot be 
expected even in the future as experience shows that potential investors are scared of ecological risks associated with military brownfields regeneration and therefore seek greenfields for investment and thus convert agricultural to construction sites.

\section{REFERENCES}

Badiali, F.,Ilieş,D.C., \& Castaldini,D. (2018). A tale of a city, through its urban landscape and cultural heritage in the heart of Europe: the case study of Oradea city (Romania), GeoJournal of Tourism and Geosites, Year XI, no. 1, vol. 21, May 2018, p.88-102.

Baskaya, T. (2010). Ways to sustainable brownfield regeneration in Istanbul, Istanbul Technical University, Faculty of Architecture, Istanbul, Vol. 7, No. 2, 76-77.

Bijelić, B., \& Filipović D. (2016). Identification and ecological aspects of large-scale brownfields in the Republic of Srpska, Spatium No. 36, December 2016, pp. 1-6.

Botić, Jurica (2013). Spatial and national distribution of foreign direct investments in Bosnia and Herzegovina, Hrvatski geografski glasnik 75/1, 131-150.

Dasgupta S., \& Tam E. (2009). Environmental review: A comprehensive review of existing classification systems of brownfield sites. Environmental Practice, 11(4): 285-300.

Dixon T. (2006). Integrating sustainability into brownfield regeneration: Rhetoric or reality? - An analysis of the UK development industry. Journal of Property Research, 23(3): 237-267.

Frank, James W. (2015): Ruins in the landscape: the Blue Hospital of Bugojno, University of Manitoba.

Frantál, B., Kunc, J., Nováková, E., Klusáček, P., Martinát, S., \& Osman, R. (2013). Location matters! Exploring brownfields regeneration in a spatial context (a case study of the South Moravian region, Czech Republic), Moravian Geographical Reports, Vol. 21, No. 2, p. 5-19.

Gegić, A. \& Husukic, E. (2017). Evaluation of the Brownfield regeneration process: Case study of Sarajevo, Bosnia and Herzegovina. Journal of Urban Regeneration and Renewal: 276-285. Volume 10 / Number 3 /Spring 2017, pp. 276-285(10), Publisher Henry Stewart Publications.

Hercik, J., Šimáček, P., Szczyrba, Z., \& Smolová, I. (2014). Military brownfields in the Czech Republic and the potential for their revitalisation, focused on their residential function, Quaestiones geographicae 33(2), pp. 127-138.

Kalberer A., Klever S.F., \& Lepke T. (eds) (2005). The future lies on brownfields. Federal Environmental Agency.

Kurtović, S., Siljković, B., \& Pavlović, N. (2014). Methods of identification and evaluation of brownfields sites, International journal of research in business and social science, Vol.3, No. 2, 105-120.

Litt J. S., \& Burke T. A. (2002). Uncovering the historic environmental hazards of urban brownfields. Journal of Urban Health 79(4): 464-481.

Matlovič R., Ira V., Sýkora L., \& Szczyrba Z. (2001). Procesy transformacyjne struktury przestrzennej miast postkomunistycznych (na przykładzie Pragi, Bratysławy, Ołomuńca oraz Preszowa) (Transformation of the spatial structure of post-communist towns: the case of Prague, Bratislava, Olomouc and Presov). In: Jażdżewska I. (ed.), Miasto postsocjalistyczne - organizacja przestrzeni miejskiej I jej przemiany (II). XIV Konwersatorium Wiedzy o Mieście, Uniwerystet Łódzki, Łódź: 243-251.

Musa, S., \& Šiljković, Ž. (2011). Geographic characteristics of landmine fields in Croatia and Bosnia and Herzegovina, IGU Chile, Santiago de Chile, 14-18.XI. 2011., acreditacion.fisa.cl//201108201956_20111174mydroa_archivo_prese.

Novosák J., \& Szczyrba Z. (2004). Frýdek-Místek: konverze tradičních prūmyslových ploch, širší vztahy geografické struktury. Urbanismus a územní rozvoj 7(2): 36-45.

Picer, N., Miošić, N., Hodak-Kobasić, V., Kovač, T., Čalić, V., \& Hrvatović, H. (2004). War waste and pollution of karstic area of Bosnia and Herzegovina with PCBS. Organohalogen compounds, Vol. 66, 1313-1320.

Simonović D. (2013). Hidden values and disputed collectivism of brownfields in the city of Banjaluka, Conference Proceedings, International Conference and Exhibition on architecture, Strand, Belgrade. 2013.

Svobodová H., \& Věžník A. (2009). To the problems of agricultural brownfields in the Czech Republic, case study of the Vysočina region. Agricultural Economics 55(11): 550- 556.

Sýkorová I. (2007). Pražské brownfields: př́ležitost i hrozba pro rozvoj metropole. Geografie-Sborník České geografické společnosti 112(3): 250-265.

Syms P. (1999). Redeveloping brownfield land. The decision-making process. Journal of Property Investment \& Finance 17(5): 481-500.

Thornton G., Franz M., Edwards D., Pahlen G., \& Nathanail P. (2007). The challenge of sustainability: incentives for brownfield regeneration in Europe. Environmental Science \& Policy, 10(2): 116-134.

Wedding G. Ch., Crawford-Brown D. (2007). Measuring site-level success in brownfield redevelopments: A focus on sustainability and green building. Journal of Environmental Management, 85(2): 483-495.

*** Economic statistics - first release. BiH foreign trade in goods statistics Jan - Aug 2018, Agency for statistics of Bosnia and Herzegovina.

Submitted:

17.07.2019
Revised:

28.10.2019
Accepted and published online 30.10.2019 